\title{
Antitumor screening of crude extracts of ten medicinal plants of Polygala genus from Southern Brazil
}

\author{
Tiago Tizziani ${ }^{1}$, Dalila Venzke ${ }^{1}$, Ana Paula Ruani ${ }^{1}$, Lucas Bonfim Marques ${ }^{2}$, Pedro Henrique Dias Moura Prazeres ${ }^{2}$, \\ Elaine Maria Souza-Fagundes ${ }^{2}$, Moacir Geraldo Pizzolatti ${ }^{1}$, Inês Maria Costa Brighente ${ }^{1 *}$ \\ ${ }^{1}$ Department of Chemistry, Federal University of Santa Catarina, Florianópolis, SC, Brazil. \\ ${ }^{2}$ Department of Physiology and Biophysics, Federal University of Minas Gerais, Belo Horizonte, MG, Brazil.
}

\begin{tabular}{|c|c|}
\hline ARTICLE INFO & ABSTRACT \\
\hline Article history: & \multirow{5}{*}{ 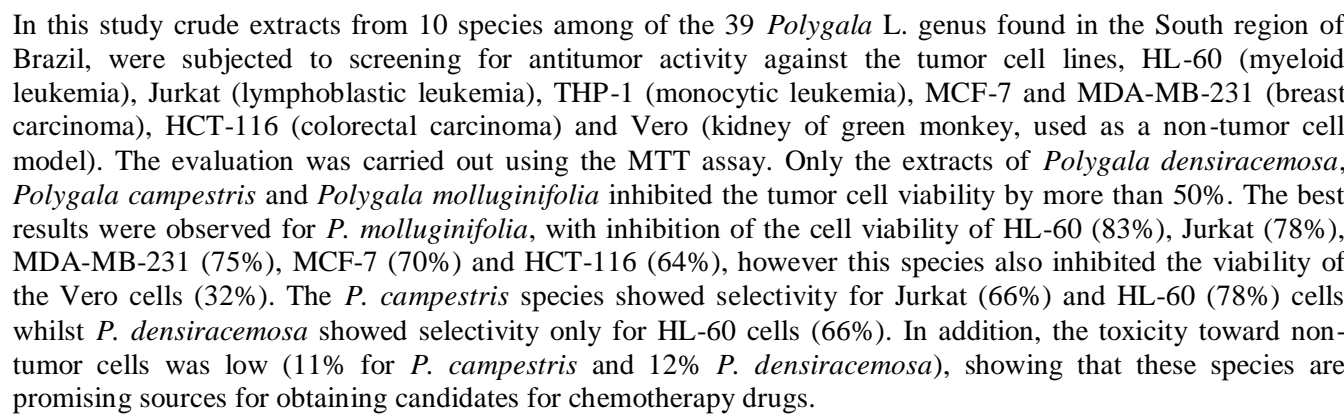 } \\
\hline Received on: $19 / 09 / 2016$ & \\
\hline ted on & \\
\hline Available online: $30 / 10 / 2017$ & \\
\hline $\begin{array}{l}\text { Key words: } \\
\text { Polygala, Polygalaceae, } \\
\text { antitumor screening, tumor } \\
\text { cell. }\end{array}$ & \\
\hline
\end{tabular}

\section{INTRODUCTION}

The Polygala L. genus is the most abundant of the Polygalaceae family, with around 725 species distributed worldwide in many different environments. In southern Brazil 39 species of this genus have been identified (Ludtke et al., 2013). The Polygala genus is characterized by the accumulation of cumarins, flavonoids, polysaccharides, sterols, styrylpyrones, triterpenic saponins and xanthones (Klein Júnior et al., 2012). Several in vitro and in vivo studies have highlighted the important biological effects of species of the genus Polygala, for instance: the anti-inflammatory activity of sterols from Polygala sabulosa (Borges etal., 2014), isoflavones from Polygala

\footnotetext{
* Corresponding Author

Inês Maria Costa Brighente, Department of Chemistry,

Federal University of Santa Catarina, Florianópolis, SC, Brazil.

Email: ines.maria@ufsc.br
}

molluginifolia (Arruda-Silva et al., 2014) and triterpenic saponins from Polygala tenuifolia (Cheong et al., 2011); the antitumor activity of polysaccharides from Polygala tenuifolia (Xin et al., 2012; Zhang et al., 2015) and xanthones from Polygala hongkongensis (Wu et al., 2011); the antidepressant activity of styrylpyrones from Polygala sabulosa (Capra et al., 2010); and the antinociceptive activity of flavonoids from Polygala paniculata (Lapa et al., 2009). Currently, chemotherapy is the main procedure for the treatment of cancer and it induces serious side effects on patients. Extensive studies seeking new active plant extracts that can be used in the treatment of cancer have been carried out in the search for drug candidates that have high efficacy and safety (Gao et al., 2005; Ni et al., 2010). This paper describes the screening of extracts of Polygala L. spp. for antitumor activity against cell lineages of different types of leukemias and carcinomas using the MTT cell viability assay. 


\section{MATERIALS AND METHODS}

\section{Plant material}

The species Polygala campestris (January 2012), Polygala linoides (September 2014) and P. sabulosa (September 2014) (deposited at the Herbarium FLOR - UFSC, under numbers 39195, 55317 and 55316, respectively) were collected in Rancho Queimado, Santa Catarina State. Polygala altomontana was collected in Bom Jardim da Serra, Santa Catarina State (October 2014) and deposited at the Herbarium FLOR - UFSC, under number 55186. Polygala longicaulis was collected in Ponta Grossa, Paraná State (December 2010) and deposited at the Herbarium FLOR - UFSC, under number 38271. Polygala molluginifolia was collected in Ponta Grossa, Paraná State (January 2012) and deposited at the Herbarium FLOR - UFSC, under number 48690. Polygala densiracemosa, Polygala lancifolia and Polygala pulchella (deposited at the Herbarium CTBS UFSC, under numbers 5009, 5005 and 5006, respectively) were collected in September 2014 in Urubici, Santa Catarina State. Polygala paniculata (deposited at the Herbarium UPCB - UFPR, under number 26027) was collected in February 2013 in Florianópolis. The plants were identified by Dr. Rafael Trevisan, Department of Botany at UFSC, Dr. Olavo de Araújo Guimarães, Department of Botany at UFPR and Dr. José Floriano Barêa Pastore, Department of Botany at UFSC - Curitibanos.

\section{Crude extracts}

The dried and powdered whole plants were extracted by exhaustive maceration (three times for seven days each time) with $\mathrm{EtOH} 96^{\circ} \mathrm{GL}$ at room temperature. The resulting extracts were combined, filtered and concentrated under reduced pressure at $50{ }^{\circ} \mathrm{C}$ to yield the crude hydroalcoholic extract. The percentages of crude extract (relative to the dried plant material) obtained were: P. campestris (18.8\%), P. linoides (11.5\%), P. sabulosa $(23.6 \%)$, P. altomontana (18.0\%), P. longicaulis (29.0\%), P. molluginifolia (27.2\%), P. densiracemosa (17.1\%), P. lancifolia (13.0\%), P. pulchella $(13.0 \%)$ and P. paniculata $(6.9 \%)$.

\section{Cell lines}

HL60 (wild-type human promyelocytic leukemia), Jurkat (human immortalized line of T lymphocyte) and THP-1 (human monocytic cell line derived from an acute monocytic leukemia patient) cell lines were donated by Dr. Gustavo Amarante-Mendes (São Paulo University, Brazil). MCF-7 and MDA-MB-231 (human breast carcinoma) cell lines were donated by Dr. Alfredo Goes (Federal University of Minas Gerais, Brazil), and HCT-116 (human colorectal carcinoma) cells were donated by Dr. Ricardo Luis A. Silva, Cancer Institute - INCA/Brazil. Vero cells (derived from the kidney of an African green monkey) were donated by Erna Kroon (Federal University of Minas Gerais, Brazil).

All lineages were maintained in the logarithmic phase of growth in RPMI 1640 or DMEM (Dulbecco's Modified Eagle Medium) supplemented with $100 \mathrm{U} \mathrm{mL}^{-1}$ penicillin and $100 \mathrm{mg}$ $\mathrm{mL}^{-1}$ streptomycin (GIBCO BRL, Grand Island, NY) enriched with $2 \mathrm{mM}$ of L-glutamine and $10 \%$ (leukemic cells) or 5\% (adherent cells) of fetal bovine serum. All cultures were maintained at $37{ }^{\circ} \mathrm{C}$ in a humidified incubator with $5 \% \mathrm{CO}_{2}$ and $95 \%$ air. The media were changed twice weekly and they were regularly examined.

\section{Evaluation of the cytotoxic effect against human tumor cell lines}

Cells were seeded at densities/well of 50,000 for HL-60 cells and 100,000 for Jurkat and THP-1 cells. Adherent cells were inoculated at 10,000 cells/well. The plates were pre-incubated for $24 \mathrm{~h}$ at $37^{\circ} \mathrm{C}$ to allow adaptation of the cells prior to the addition of the extracts. Freshly prepared solutions of the different extracts were screened at $50 \mu \mathrm{g} \mathrm{mL} \mathrm{m}^{-1}$ in DMSO. Subsequently, the plates were inoculated for $48 \mathrm{~h}$ in an atmosphere of $5 \% \mathrm{CO}_{2}$ and $100 \%$ relative humidity. Control groups included treatment with $0.5 \%$ DMSO (negative control) and etoposide (10 $\mu \mathrm{M}$, positive control). Cell viability was estimated by measuring the rate of mitochondrial reduction of MTT. All substances were dissolved in dimethylsulfoxide (DMSO) prior to dilution, with a final cell concentration of $0.5 \%$. All extracts were tested in triplicate, in two independent experiments.

\section{In vitro cell viability assay - MTT assay}

Cell viability was evaluated using the MTT assay as described by Mosmann (1983). Briefly, after $4 \mathrm{~h}$ of incubation of the cells with the different extracts, $20 \mu \mathrm{L}$ of MTT solution $(5 \mathrm{mg}$ $\mathrm{mL}^{-1}$ in phosphate-buffered saline) were added to each well, the supernatant was removed and $200 \mu \mathrm{L}$ of $0.04 \mathrm{M} \mathrm{HCl}$ in isopropyl alcohol were added to dissolve the formazan crystals. The optical densities (OD) were evaluated using a spectrophotometer at 595 $\mathrm{nm}$. Controls included drug-containing medium (background) and extract-free complete medium. Extract-free complete medium was used as the control (blank) and was treated in the same way as the extract-containing media. Results were expressed as percentage of cell proliferation, compared with the $0.5 \%$ DMSO control and were calculated as follows: viability $(\%)=$ (mean OD treated culture - mean OD background)/(mean OD untreated culture, i.e. $0.5 \%$ DMSO - mean OD blank wells) $x$ 100. Interaction of the extract with the medium was estimated on the basis of the variations between the drug-containing medium and the extractfree medium to avoid false-positive or false-negative results in relation to the control (Ulukaya et al., 2004).

\section{RESULTS AND DISCUSSION}

In the experiments six tumor cell lines and one line of non-tumor cells (Vero) were evaluated. This latter lineage has been used in toxicity studies as a predictive model of normal cells (Freire et al., 2008). Three cell lines were derived from colorectal carcinoma (HCT-116) and two from breast cancer cells: an estrogen-dependent lineage represented by MCF-7 (responsive to chemotherapy) and an aggressive and unresponsive estrogenindependent lineage MDA-MB-231 (Srisawat et al., 2014). 
Table 1: Effect of crude plant extracts on proliferation/ viability of tumor cells and non-tumor cells (Vero).

\begin{tabular}{|c|c|c|c|c|c|c|c|}
\hline \multirow{2}{*}{ Extracts } & \multicolumn{7}{|c|}{$\%$ inhibition of proliferation } \\
\hline & HL-60 & MCF-7 & MDA-MB-231 & JURKAT & HCT-116 & THP-1 & VERO \\
\hline P. altomontana & $10.37 \pm 3.70$ & $8.55 \pm 2.72$ & $19.55 \pm 4.80$ & $34.21 \pm 4.28$ & \# & $\#$ & \# \\
\hline P. campestris & $78.57 \pm 0.47$ & $30.47 \pm 2.32$ & \# & $66.05 \pm 4.43$ & \# & $49.26 \pm 4.82$ & $11.69 \pm 4.90$ \\
\hline P. densiracemosa & $66.24 \pm 1.01$ & $11.87 \pm 3.34$ & $20.37 \pm 4.49$ & $52.36 \pm 0.34$ & $\#$ & $28.36 \pm 4.05$ & $12.64 \pm 3.57$ \\
\hline P. lancifolia & \# & $12.65 \pm 4.73$ & $6.57 \pm 1.33$ & $2.48 \pm 2.59$ & \# & \# & \# \\
\hline$P$. linoides & $7.13 \pm 3.17$ & $8.69 \pm 2.37$ & $7.97 \pm 4.57$ & $28.43 \pm 4.48$ & \# & \# & \# \\
\hline P. longicaulis & \# & $13.92 \pm 3.16$ & $11.75 \pm 3.11$ & \# & \# & $9.21 \pm 4.28$ & $13.14 \pm 0.17$ \\
\hline P. molluginifolia & $83.26 \pm 0.67$ & $69.98 \pm 0.17$ & $75.04 \pm 0.37$ & $78.39 \pm 0.22$ & $64.26 \pm 4.89$ & $35.03 \pm 4.35$ & $32.54 \pm 4.65$ \\
\hline P. paniculata & $46.05 \pm 4.38$ & $13.85 \pm 3.56$ & $23.14 \pm 4.36$ & $55.96 \pm 4.29$ & \# & $7.94 \pm 0.07$ & \# \\
\hline P. pulchella & $30.56 \pm 1.95$ & $3.96 \pm 0.07$ & $16.48 \pm 4.07$ & $31.23 \pm 1.83$ & \# & \# & \# \\
\hline P. sabulosa & \# & \# & $6.71 \pm 0.93$ & $12.27 \pm 1.60$ & \# & \# & \# \\
\hline Etoposide* & $71.06 \pm 4.81$ & $27.93 \pm 4.23$ & $6.25 \pm 4.85$ & $39.33 \pm 5.01$ & $29.65 \pm 4.13$ & $72.37 \pm 4.61$ & $21.28 \pm 1.31$ \\
\hline
\end{tabular}

*positive control $10 \mu \mathrm{M}$; \# stimulated cell proliferation.

To represent models of relevant leukemias with an impact on public health, cells derived from the human promyelocytic leukemic (HL-60 cells), acute T-lymphocytic leukemia (Jurkat) and acute monocytic leukemia (THP-1) were used. The cell lines were evaluated by the MTT method in which the tetrazolium salt is reduced to purple formazan crystals mainly by mitochondrial succinate dehydrogenase and the color intensity of the formazan dye is correlated to the number of viable cells (Mosmann, 1983). The results demonstrate that only $P$. densiracemosa, $P$. campestris and $P$. molluginifolia inhibited by more than $50 \%$ the proliferation of tumor cells and presented low inhibition of the proliferation of non-tumor cells (Figure 1 and 2), which is a parameter for antitumor screening (Senthilraja et al., 2015). The $P$. densiracemosa sample was active only in the inhibition of the HL-60 strain (66\%) and Vero cell viability (12\%), suggesting a possible selectivity for myeloid leukemia cells and low toxicity against non-tumor cells. The P. campestris sample inhibited the viability of Jurkat (66\%) and HL-60 (78\%) cells, with low toxicity toward Vero cells $(11 \%)$. The $P$. molluginifolia sample inhibited by over $50 \%$ the proliferation in 5 of the 6 tumor cell lines tested: HL-60 (83\%), Jurkat (78\%), MDA-MB-231 (75\%), MCF-7 (70\%) and HCT-116 (64\%). However, the Vero cell viability was inhibited by $32 \%$, demonstrating cytotoxicity also toward non-tumor cells (Figure 1 and Table 1). Isoflavones are the main secondary metabolites of $P$. molluginifolia (Venzke $e t$ $a l$. , 2013), which may be related to the pronounced anti-tumor activity of this species (De la Parra et al., 2016).

Polygala campestris and $P$. densiracemosa, in preliminary studies, showed the accumulation of xanthones (unpublished data), which may explain the cell inhibition profile (HL-60 and Jurkat) and low toxicity against non-tumor cells. Previous studies have demonstrated the potent activity of xanthones isolated from $P$. hongkongensis against three tumor cell lines (HepG2 human hepatocellular carcinoma cells; GLC-82 human lung carcinoma cells and MCF-7 human breast carcinoma cells), using the MTT assay (Wu et al., 2011). In another study, the antitumor activity of a root extract of Polygala senega was demonstrated (Paul et al., 2010).
One of the important criteria for a candidate antitumor drug is to have minimal or no side effects on the normal cells of patients undergoing chemotherapy. One way to achieve this is by employing lower doses of the drug. This invariably means that the drug should not only have potent activity, but should also display a high degree of selectivity (Badisa et al., 2009).

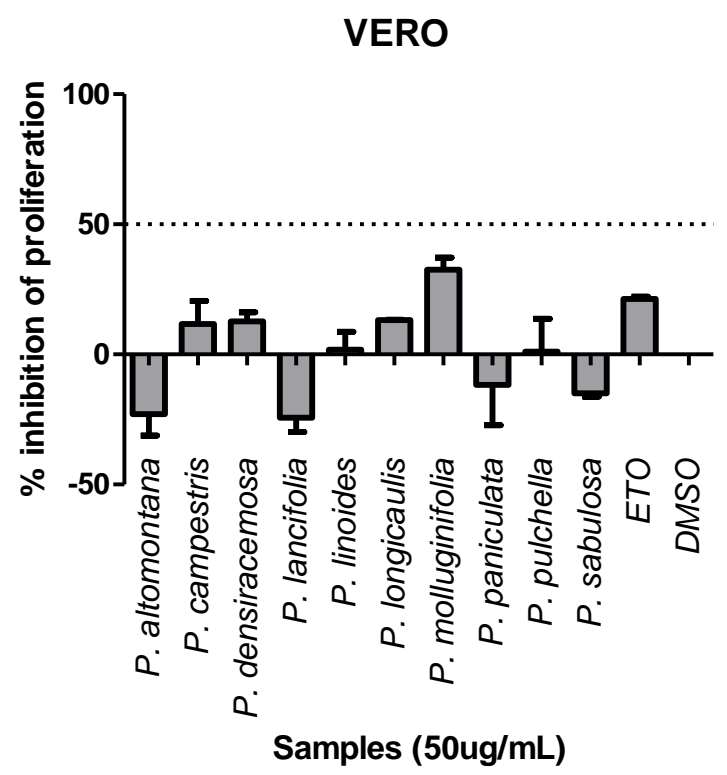

Fig. 1: Effect of crude plant extracts on proliferation/ viability of non-tumor cells (Vero). Data representative of two independent experiments performed in triplicate. Control groups included treatment with $0.5 \%$ DMSO (negative control) and etoposide $(10 \mu \mathrm{M}$, positive control).

The $P$. campestris sample showed selectivity for cell lines of lymphoid and myeloid leukemia while $P$. densiracemosa showed selectivity only for myeloid cells, and both species presented low toxicity toward non-tumor cells. The species $P$. molluginifolia demonstrated the highest inhibition values for tumor cells, as can be seen in Figure 2, where $83 \%$ cell proliferation can be observed for HL-60 cells, suggesting a potent antitumor activity. However, this species also inhibited the viability of non-tumor cells lines by $32 \%$. 


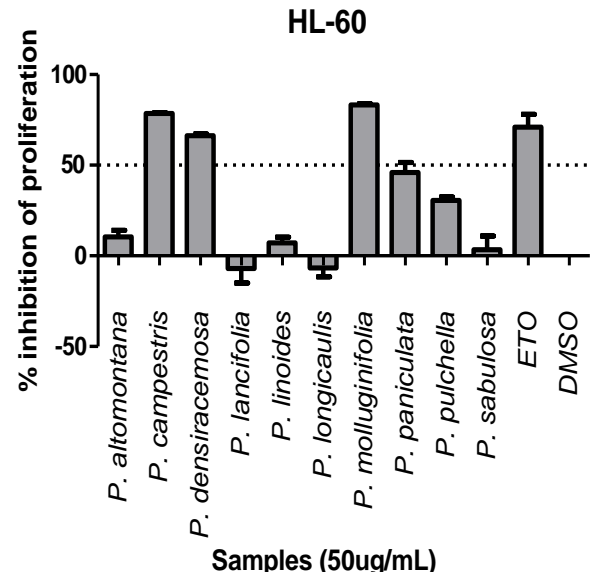

JURKAT

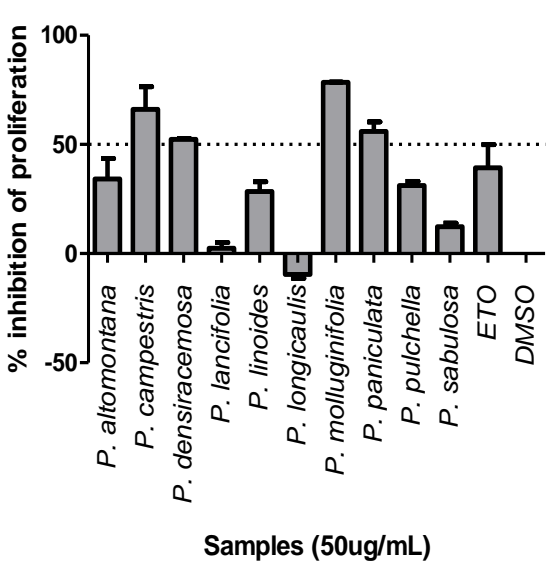

MCF-7

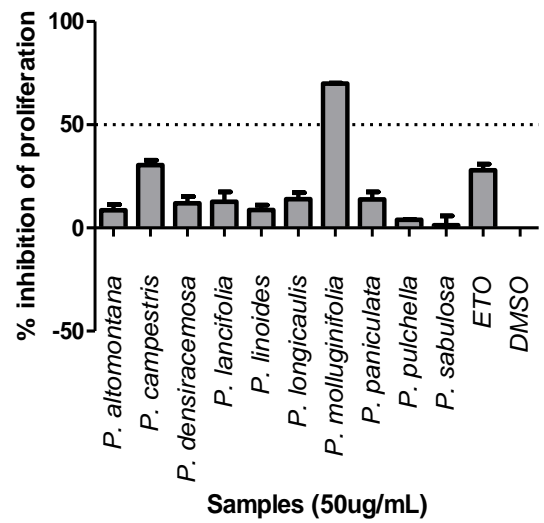

HCT-116

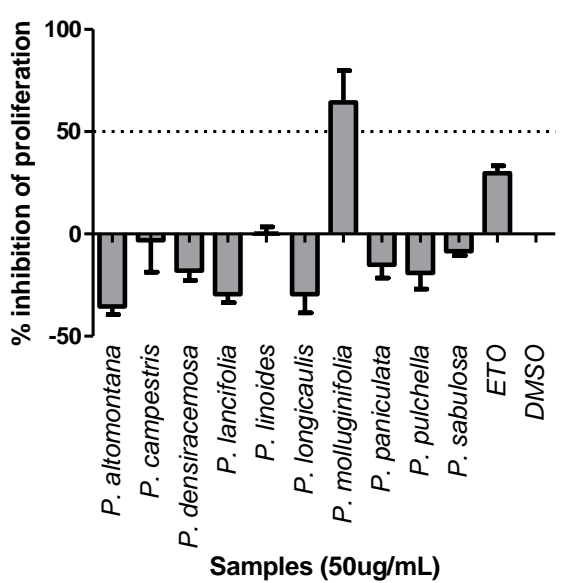

MDA-MB-231

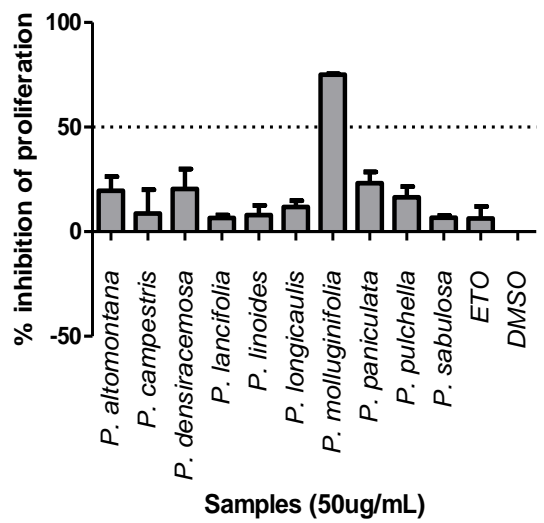

THP-1

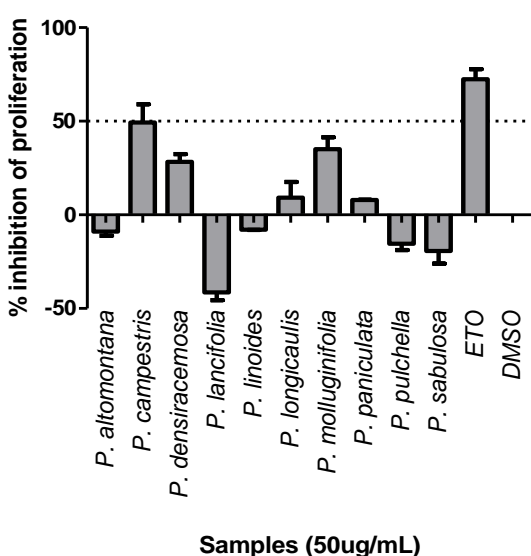

Fig. 2: Effect of crude plant extracts on proliferation/ viability of tumor cells. Data representative of two independent experiments performed in triplicate. Control groups included treatment with $0.5 \%$ DMSO (negative control) and etoposide (10 $\mu \mathrm{M}$, positive control).

\section{CONCLUSIONS}

The best results found for antitumor screening were observed for the $P$. molluginifolia sample, but this species also inhibited the viability of Vero cells.

The species $P$. campestris showed selectivity for Jurkat and HL-60 cells whilst $P$. densiracemosa showed selectivity only for HL-60 cells, with low toxicity toward non-tumor cells. These results demonstrate that $P$. densiracemosa and $P$. campestris are promising sources for obtaining candidates for chemotherapy drugs.

\section{ACKNOWLEDGMENTS}

The authors are grateful to Prof. Dr. Rafael Trevisan, Prof. Dr. José Floriano Barêa Pastore and Prof. Dr. Olavo de Araújo Guimarães for identifying the plant material.

Financial support and sponsorship: Authors thankful to $\mathrm{CNPq}$, CAPES and FAPEMIG for financial support.

Conflict of Interests: There are no conflicts of interest.

\section{REFERENCES}

Arruda-Silva F, Nascimento MVPS, Luz ABG, Venzke D, Queiroz GS, Frode TS, Pizzolatti MG. Dalmarco EM. Polygala molluginifolia A. St.-Hil. and Moq. prevent inflammation in the mouse pleurisy model by inhibiting NF-kB activation. Int Immunopharmacol, 2014; 19:334-341.

Badisa RB, Darling-Reed SF, Joseph P, Cooperwood JS, Latinwo LM, Goodman CB. Selective cytotoxic activities of two novel synthetic drugs on human breast carcinoma MCF-7 cells. Anticancer Res, 2009; 29:2993-2996.

Borges FRM, Silva MD, Córdova MM, Schambach TR, Pizzolatti MG, Santos ARS. Anti-inflammatory action of hydroalcoholic extract, dichloromethane fraction and steroid $\alpha$-spinasterol from Polygala sabulosa in LPS-induced peritonitis in mice. J Ethnopharmacol, 2014; 151:144-150.

Capra JC, Cunha MP, Machado DG, Zomkowski ADE, Mendes BG, Santos ARS, Pizzolatti MG, Rodrigues ALS. Antidepressant-like effect of scopoletin, a coumarin isolated from Polygala sabulosa (Polygalaceae) in mice: evidence for the involvement of monoaminergic systems. Eur J Pharmacol, 2010; 643:232-238.

Cheong M, Lee S, Yoo H, Jeong J, Kim G, Kim W, Jung I, Choi Y. Anti-inflammatory effects of Polygala tenuifolia root through inhibition of NF-B activation in lipopolysaccharide-induced BV2 microglial cells. J Ethnopharmacol, 2011; 137:1402-1408.

De la Parra C, Castillo-Pichardo L, Cruz- Collazo A, Cubano L, Redis R, Calin GA, Dharmawardhane S. Soy isoflavonegenistein-mediated 
downregulation of miR-155 contributes to the anticancer effects of genistein. Nutr cancer, 2016; 68:154-164.

Freire PF, Martin JMP, Herrero O, Peropadre A, De la Peña E, Hazen MJ. In vitro assessment of the cytotoxic and mutagenic potential of perfluorooctanoic acid. Toxicol In Vitro, 2008; 22:1228-1233.

Gao Y, Gao H, Chan E. Tang W, Xu A, Yang H, Huang M, Lan $\mathrm{J}$, Li X, Duan W, Xu C, Zhou S. Antitumor activity and underlying mechanisms of ganopoly, the refined polysaccharides extracted from Ganoderma lucidum, in mice. Immunol Invest, 2005; 34:171-198.

Klein Junior LC, Andrade SF, Cechinel Filho V. A Pharmacognostic approach of the Polygala genus: Phytochemical and Pharmacological Aspects. Chem Biodivers, 2012; 9: 181-209.

Lapa FDR, Gadotti VM, Missau FC, Pizzolatti MG, Marques MCA, Dafré AL, Farina M, Rodrigues ALS, Santos ARS. Antinociceptive properties of the hydroalcoholic extract and the flavonoid rutin obtained from Polygala paniculata L. in mice. Basic Clin Pharmacol Toxicol, 2009; 104: 306-315.

Lüdtke R, De Souza-Chies TT, Miotto STS. O gênero Polygala L.(Polygalaceae) na Região Sul do Brasil. Hoehnea, 2013; 40:1-50.

Mosmann T. Rapid colorimetric assay for cellular growth and survival: application to proliferation and cytotoxicity assays. J Immunol Methods, 1983; 65:55-63.

Ni W, Zhang X, Wang B, Chen Y, Han H, Fan Y, Zhou Y, Tai G. Antitumor activities and immunomodulatory effects of Ginseng neutral polysaccharides in combination with 5-fluorouracil. J Med Food, 2010; 13:270-277.

Paul S, Mandal SK, Bhattacharyya SS, Boujedaini N, KhudaBukhsh AR. In vitro and in vivo studies demonstrate anticancer property of root extract of Polygala senega.J Acupunct Meridian Stud, 2010; 3:188196.

Senthilraja P, Kathiresan K, In vitro cytotoxicity MTT assay in Vero, HepG2 and MCF -7 cell lines study of Marine Yeast. J App Pharm Sci, 2015; 5: 80-84.

Srisawat T, Sukpondma Y, Chimplee S, Kanokwiroon K, Tedasen A, Graidist P. Extracts from Vatica diospyroides type SS fruit show low dose activity against MDA-MB-468 breast cancer cell-line via apoptotic action. Biomed Res Int, 2014; 2014:479602-479609.
Ulukaya E, Colakogullari M, Wood EJ. Interference by anticancer chemotherapeutic agents in the MTT-tumor chemosensitivity assay. Chemotherapy, 2004; 50:43-50.

Venzke D, Carvalho FK, Ruani AP, Oliveira AS, Brighente IMC, Micke GA, Barison A, Pizzolatti, MG. PAMPA Permeability, acetylcholinesterase inhibition and antioxidant activity of pyranoisoflavones from Polygala molluginifolia (Polygalaceae). J Braz Chem Soc, 2013, 24:1991-1997.

Wu J, Tu P, Zhan H, Gao J. Dioxyxanthones from Polygala hongkongensis and their cytotoxicity. Chem Res Chinese Universities, 2011; 27: 777-779.

Xin T, Zhang F, Jiang Q, Chen C, Huang D, Li Y, Shen W, Jin Y. Extraction, purification and antitumor activity of a water-soluble polysaccharide from the roots of Polygala tenuifolia. Carbohydr Polym, 2012; 90:1127-1131.

Zhang F, Song X, Li L, Wang J, Lin L, Li C, Li H, Lv Y, Jin Y, Liu Y, Hu Y, Xin T. Polygala tenuifolia polysaccharide inducer apoptosis in ovarian cancer cells via a mitochondrial pathway. Tumor Biol, 2015; 36:2913-2919.

\section{How to cite this article:}

Tizziani T, Venzke D, Ruani AP, Marques LB, Prazeres PHD, Souza-Fagundes EM, Pizzolatti MG, Brighente IMC. Antitumor screening of crude extracts of ten medicinal plants of Polygala genus from Southern Brazil. J App Pharm Sci, 2017; 7 (10): 079083. 